\title{
Lebanon
}

Having decided to include the Geneva Conventions in the pro\& amme of study and written examinations at the Military College, t. E Lebanese Army has asked its country's Red Cross to assume : sponsibility for six courses on these Conventions.

Mrs. Selim Saab, member of the Central Committee of the "ational Society has been put in charge of this course. In addition, tie book which she has written on the Red Cross and the Geneva Convertions and of which the International Reriew mentioned its Jublication in its issue of June 1966, has been presented to officer $\therefore$ dets attending the course. It serves them as a work of reference.

The Reriew of the Lebanese Red Cross (No. 24) points out in tis connection with what interest the young men followed Mrs. $\because a b$ 's talks, the appositeness of their questions and their determina$\therefore$ so to understand and follow the regulations of international ramanitarian law. It iightly recalls that the bonds uniting the armed forces with the Red Cross in many countries, the latter being an ausiliary service to the former, originate from the events which took place more than a century ago at Solferino.

\section{Santo Domingo}

Mr. Pierre Jequier, delegate of the ICRC, wisited Santo Domingo at the besinning of December 1966. He was received by the Deputy Minister of Foreign Affairs with whom he discussed an importan: problem, that of disseminating the Genewa Conientions. He then wer: to the Dominican Red Cross where he met Mr. Manuel E. Saladir Velez who informed him of the present main activities of the Nationat Socicty oier which he presides and in particular of the efforts beins make to rehabilitate the disabled. We publish the following notes or the basis of information collected by Mr. Jequier, which give som! 